\title{
Aleurites moluccana (L.) Willd. Leaves: Mechanical Antinociceptive Properties of a Standardized Dried Extract and Its Chemical Markers
}

\author{
Nara L. M. Quintão, Christiane Meyre-Silva, Gislaine F. Silva, \\ Carla S. Antonialli, Lilian W. Rocha, Ruth M. Lucinda-Silva, Angela Malheiros, \\ Márcia M. Souza, Valdir Cechinel Filho, and Tania M. B. Bresolin
}

Programa de Mestrado em Ciências Farmacêuticas, Núcleo de Investigações Químico-Farmacêuticas (NIQFAR), Universidade do Vale do Itajaí (UNIVALI), Rua Uruguai, 458, 88302-202, Itajaí, Itajaí, SC, Brazil

Correspondence should be addressed to Tania M. B. Bresolin, tbresolin@univali.br

Received 20 December 2010; Accepted 31 January 2011

Copyright (C) 2011 Nara L. M. Quintão et al. This is an open access article distributed under the Creative Commons Attribution License, which permits unrestricted use, distribution, and reproduction in any medium, provided the original work is properly cited.

\begin{abstract}
Seeking to develop a new analgesic phytomedicine, a spray-dried extract (SDE) of Aleurites moluccana (L.) Willd. leaves was developed in scale up $(5 \mathrm{~kg})$. The SDE was standardized at $3 \% \mathrm{w} / \mathrm{w}$ in relation to the flavonoid $2^{\prime \prime}$-O-rhamnosylswertisin. The SDE batches were evaluated in relation to their physical, physiochemical, and pharmacological characteristics. The results demonstrated the reproducibility of the scale up SDE process which, when dosed orally, reduced carrageenan-induced mechanical hypernociception, with an $\mathrm{ID}_{50} \%$ of $443 \mathrm{mg} / \mathrm{kg}$. Similar results were obtained with animals injected with complete Freund's adjuvant (CFA), in which SDE caused inhibition of $48 \pm 4 \%$. SDE was effective in preventing prostaglandin E2 (PGE2)-induced mechanical hypernociception (inhibition of $26 \pm 10 \%$ and $33 \pm 3 \%$, at 250 and $500 \mathrm{mg} / \mathrm{kg}$, respectively). Swertisin and $2^{\prime \prime}-$ $O$-rhamnosylswertisin isolated from the own extract were effective in inhibiting the hypernociceptive response induced by carrageenan $\left(70 \pm 2 \%\right.$ and $50 \pm 5 \%$, resp.). Furthermore, $2^{\prime \prime}-O$-rhamnosylswertisin was capable of significantly inhibiting the mechanical sensitization induced by CFA or PGE2, with inhibitions of $25 \pm 3 \%$ and $94 \pm 6 \%$, respectively. These results suggest that the effects of SDE are related, at least in part, to the presence of these flavonoids.
\end{abstract}

\section{Introduction}

Aleurites moluccana (L.) Willd., Euphorbiaceae, popularly known as "Candlenut tree" or "Indian Walnut", among other names, is a native plant to Malaysia, Polynesia, and the South Sea Islands, with wide distribution throughout the tropics. It is a medium-sized tree, up to $10 \mathrm{~m}$ tall, which grows abundantly throughout the south and southeast of Brazil (São Paulo to Rio Grande do Sul). It is used in folk medicine for the treatment of fever, inflammation, asthma, hepatitis, headache, gastric ulcer, and so forth. Its seeds are used as an antirheumatic and as a fertilizer [1,2]. Previous studies have demonstrated that the dichloromethane fraction obtained from the leaves and bark of A. moluccana presents antiviral activity [3], as well as antibacterial effects against Staphylococcus aureus and Pseudomonas aeruginosa [4]. The methanol extract from the leaves of this plant exhibited hypolipidemic effects [5].

A. moluccana was introduced to Brazil in the 1980s as an ornamental tree and is an important source of the oil used in tannery [6]. There is a large area in Santa Catarina State (Brazil) with more than 6,000 trees that can furnish sufficient raw material for the pharmaceutical industry, and the culture of domesticated species has already begun. Studies conducted by our research group have demonstrated the performance of the tree after some types of cutting and have found that it develops well, requiring three to four months to germinate. The purpose of these studies is to assure the vegetable raw material source without interfering in the growth of the tree, thereby ensuring sustainable management of the biodiversity that culminates in the development of a herbal medicine [7]. These results are in agreement with 
previous studies, which observe that it can withstand both high and low $\mathrm{pH}$ values, poor soils, slopes, and annual rainfall of 6.4 to $42.9 \mathrm{dm}$ [6].

Previous experimental studies conducted by our research group have also demonstrated that the hydroalcoholic extract of $A$. moluccana leaves and its hexane fraction exhibit antinociceptive effects, inhibiting acetic-acid-induced abdominal writhing in mice [8]. This activity may be related to the presence of $2^{\prime \prime}$-O-rhamnosylswertisin, a flavone $C$-glycoside, which caused $92 \pm 4 \%$ inhibition when evaluated in the same model [9]. However, a more friendly technological extract needs to be developed, with a view to enabling industrial production of a herbal medicinal product, which must be obtained on a large scale and standardized in relation to a chemical marker, with stability, safety, and proven efficacy in preclinical and clinical studies, for further licensing by the regulatory agencies for marketing and purposes, under patent [7].

The aim of this work, therefore, is to obtain a reproducible spray-dried extract (SDE) in the scaleup, standardized in relation to a chemical marker, the flavonoid $2^{\prime \prime}$ $O$-rhamnosylswertisin $(\mathrm{MW}=592 \mathrm{~g}$ ), the major compound evidenced in the selected extract of $A$. moluccana leaves, and to evaluate the antinociceptive effect of the technological product, SDE, and two purified substances, $2^{\prime \prime}-O$ rhamnosylswertisin and swertisin, on different experimental models of pain in mice.

\section{Materials and Methods}

2.1. Collection of Plant Materials. Leaves of A. moluccana Willd. were collected in July 2007 in Tijucas, in the State of Santa Catarina, Brazil, and identified by Professor Dr. Ademir Reis (Department of Botany/UFSC, Florianópolis, $\mathrm{SC}$, Brazil). A voucher specimen was deposited at the Barbosa Rodrigues Herbarium (Itajaí, SC, Brazil) under number VC Filho 001.

2.2. Preparation of Standardized Dried Extract. Three batches of dried extracts were prepared at Centroflora (Botucatu, SP, Brazil) on a pilot scale ( $5 \mathrm{~kg}$ ) using extractive conditions optimized in previous works carried out by our group. $70 \mathrm{~kg}$ of dried herbal drug was macerated in a reactor for 5 days without stirring, with $700 \mathrm{~L}$ of $70: 30(\mathrm{v} / \mathrm{v})$ ethanol: water solution at room temperature. The solution was then percolated, passed through a filter wheel $(40 \mathrm{~mm})$ then passed through Nutshell filter with filter paper. The solution was concentrated in Bernauer concentrator at $70^{\circ} \mathrm{C}$ under vacuum $(400 \mathrm{mmHg})$, to obtain total solids of approximately $40 \%$. The concentrate was mixed with about $25 \%$ (w/w total solids of concentrate) of colloidal silicon dioxide and dried in an industrial spray dryer (GEA Niro, Søborg, Denmark) with an inlet temperature of $165-180^{\circ} \mathrm{C}$ and an outlet temperature of $70-80^{\circ} \mathrm{C}$.

The dried extracts were analyzed: morphological aspect by scaning electron microscopy (SEM) with magnification of $60 \mathrm{x}$, color, taste/odor, moisture, $\mathrm{pH}$ (10\% solution in water), aqueous solubility (concentration of $10 \%$ ), and bulk density, according to the methodology described in the United States Pharmacopeia [10].

The extracts were standardized by high-performance liquid chromatography (HPLC), based on the marker content, $2^{\prime \prime}$-O-rhamnosylswertisin, using the methodology described below.

2.2.1. Isolation, Identification and Purity Determination of Swertisin and 2-O-Rhamnosylswertisin. Milled air-dried leaves of $A$. moluccana ( $600 \mathrm{~g}$ ) were extracted with methanol at room temperature for 7 days. The solution was then evaporated in a vacuum to obtain methanol crude extract (yield of $8.5 \%$ ). Purification procedures (chromatographic column-CC) were conducted with crude methanol extract using silica gel 60 (70-230 mesh) and elution with increasing concentrations of methanol in dichloromethane to give nine fractions (I-IX). Fractions I and II were grouped and submitted to silica gel CC eluted with a mixture of dichloromethane and methanol in step-gradient mode, to yield swertisin (1) (Figure 1) in the form of a yellow, amorphous powder $(20 \mathrm{mg}), \mathrm{mp} 242.6$ to $243.4^{\circ} \mathrm{C}$. The chemical structure was confirmed by NMR- ${ }^{1} \mathrm{H}$ and ${ }^{13} \mathrm{C}$, as previously reported $[11,12]$. Similarly, fractions III and IV were grouped and submitted to silica gel CC eluted with a mixture of dichloromethane and methanol as eluent, with increasing polarity, followed by flash chromatography eluted with a mixture of dichloromethane and methanol $(8: 3)$ to yield $2^{\prime \prime}$-O-rhamnosylswertisin (2) (Figure 1) in the form of a yellow powder $(490 \mathrm{mg})$. The chemical structure was confirmed by $\mathrm{NMR}-{ }^{1} \mathrm{H}$ and ${ }^{13} \mathrm{C}$ as previously reported $[11,13]$.

Swertisin (1) is an amorphous powder, mp 242.6$243.4^{\circ} \mathrm{C}$. The isolated compound was confirmed by NMR spectroscopy using a Bruker AC-300 instrument, operating at $300 \mathrm{MHz}$ for ${ }^{1} \mathrm{H}$ and $75.5 \mathrm{MHz}$ for ${ }^{13} \mathrm{C}$ and using $\mathrm{CD}_{3} \mathrm{OD}$ as solvent. ${ }^{1} \mathrm{H}$ NMR: $3.15-3.90(\mathrm{~m}, 6 \mathrm{H}$, of Glc), $3.94(3 \mathrm{H}$, s, $\left.\mathrm{OCH}_{3}\right), 4.40\left(1 \mathrm{H}, \mathrm{m}, \mathrm{H}^{\prime \prime}\right), 6.63(1 \mathrm{H}, \mathrm{s}, \mathrm{H} 3), 6.71(1 \mathrm{H}, \mathrm{s}$, $\mathrm{H} 8), 6.90\left(2 \mathrm{H}, \mathrm{d}, j=8.8, \mathrm{H}^{\prime}, \mathrm{H} 5^{\prime}\right), 7.80(2 \mathrm{H}, \mathrm{d}, j=8.8$, $\left.\mathrm{H} 2^{\prime}, \mathrm{H}^{\prime}\right) .{ }^{13} \mathrm{C}$ NMR: $55.9\left(\mathrm{OCH}_{3}\right), 63.3\left(\mathrm{C} 6^{\prime \prime}\right), 71.4\left(\mathrm{C}^{\prime \prime}\right)$, 72.1 (C1" $), 74.6\left(\mathrm{C}^{\prime \prime}\right), 80.9\left(\mathrm{C}^{\prime \prime}\right), 83.2\left(\mathrm{C}^{\prime \prime}\right), 96.9(\mathrm{C} 3)$, 101.4 (C8), 101.5 (C10), 111.8 (C6), 116.8 (C3', C5'), 121.8 $\left(\mathrm{C1}^{\prime}\right), 128.7$ (C2', $\left.\mathrm{C6}^{\prime}\right), 157.5$ (C5), $161.6\left(\mathrm{C}^{\prime}\right), 162.5$ (C9), 164.4 (C1), 164.5 (C7), and 182.8 (C4).

$2^{\prime \prime}$-O-rhamnosylswertisin (2) an amorphous powder, mp 260.5-261.0 ${ }^{\circ} \mathrm{C}$. NMR spectroscopy $\left(\mathrm{CD}_{3} \mathrm{OD}\right) .{ }^{1} \mathrm{H}$ NMR: $0.65\left(3 \mathrm{H}, \mathrm{d}, J=6.0, \mathrm{H}^{\prime \prime \prime}\right), 3.10-3.90(\mathrm{~m}, 6 \mathrm{H}$, of Glc, $5 \mathrm{H}$ rham $) 3.96\left(3 \mathrm{H}, \mathrm{s}, \mathrm{OCH}_{3}\right), 4.55\left(1 \mathrm{H}, \mathrm{m}, \mathrm{H} 1^{\prime \prime}\right), 5.11(1 \mathrm{H}$, $\left.\mathrm{m}, \mathrm{H}^{\prime \prime \prime}\right), 6.67(1 \mathrm{H}, \mathrm{s}, \mathrm{H} 3), 6.76(1 \mathrm{H}, \mathrm{s}, \mathrm{H} 8), 6.93(2 \mathrm{H}, \mathrm{d}$, $\left.j=9.0, \mathrm{H}^{\prime}, \mathrm{H}^{\prime}\right), 7.89$ (2H, d, $\left.j=9, \mathrm{H}^{\prime}, \mathrm{H}^{\prime}\right) .{ }^{13} \mathrm{C} \mathrm{NMR}$ : $18.0\left(\mathrm{C} 6^{\prime \prime \prime}\right), 55.9\left(\mathrm{OCH}_{3}\right), 62.4\left(\mathrm{C}^{\prime \prime}\right), 64.4\left(\mathrm{C}^{\prime \prime \prime}\right), 70.0$ $\left(\mathrm{C}^{\prime \prime}\right), 72.1$ (C2 $\left.{ }^{\prime \prime \prime}\right), 72.2\left(\mathrm{C}^{\prime \prime \prime}\right), 72.5\left(\mathrm{C}^{\prime \prime \prime}\right), 73.6\left(\mathrm{C}^{\prime \prime}\right)$, $76.9\left(\mathrm{C}^{\prime \prime}\right), 79.0\left(\mathrm{C}^{\prime \prime}\right), 81.8\left(\mathrm{C}^{\prime \prime}\right), 102.3(\mathrm{C} 3), 103.1\left(\mathrm{C}^{\prime \prime \prime}\right)$, 103.7 (C8), 103.9 (C10), 111.1 (C6), 117.8 (C3', C5'), 121.9 $\left(\mathrm{C1}^{\prime}\right)$, 129.7 (C2' $\left.\mathrm{C} 6^{\prime}\right), 159.2$ (C5), 159.5 (C4'), 165.5 (C9), 165.0 (C1), 167.0 (C7), and 184.0 (C4).

MS analysis was performed in the LC-MS/MS system: SCL-10AVP system controller (Shimadzu), LC-10ADVP solvent delivery system and an FCV-10ALVP valve (Shimadzu Corp., Kyoto, Japan) with a Micromass Quattro LC mass 
<smiles>COc1cc2oc(-c3ccc(O)cc3)cc(=O)c2c(O)c1C1O[C@H](CO)[C@@H](O)[C@H](O)[C@H]1O</smiles>

(1) Swertisin

(a)<smiles>COc1cc2oc(-c3ccc(O)cc3)cc(=O)c2c(O)c1C1O[C@H](CO)[C@@H](O)[C@H](O)C1OC1OC(C)[C@H](O)[C@H](O)C1O</smiles>

(2) 2" -O-rhamnosylswertisin

(b)

Figure 1: Chemical structure of (1) Swertisin and (2) 2"-O-rhamnosylswertisin.

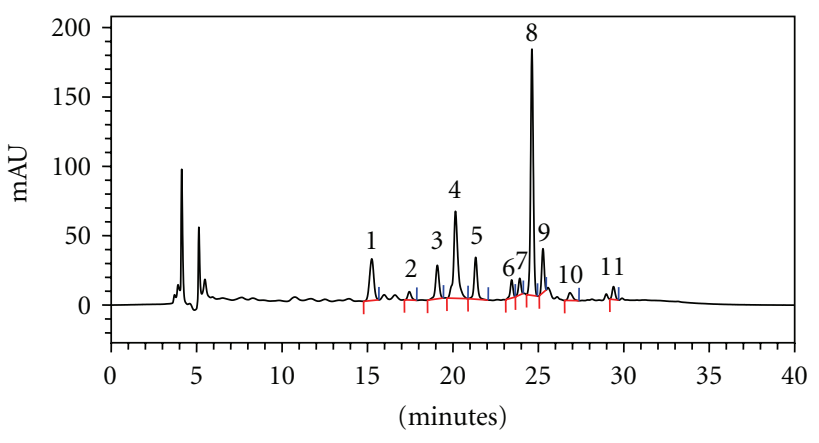

(a)

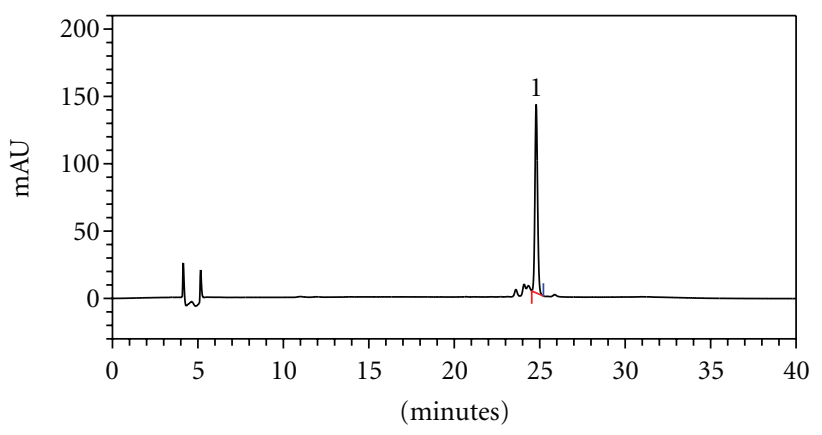

(b)

Figure 2: (a) Typical chromatogram of $A$. moluccana dried extract; (b) $2^{\prime \prime}$-O-rhamnosylswertisin chromatogram.

spectrometer (Waters Corp., Milford, MA) in tandem) by infusion of the compound added to a solvent flow of $0.6 \mathrm{~mL} / \mathrm{min}$, split $1: 3$, acetonitrile: $50 \mathrm{mM}$ ammonium acetate $(90: 10, \mathrm{v} / \mathrm{v})$. This was brought into the MS via an ESI source and measured in the negative ion mode. Nebulization was achieved using nitrogen gas at a pressure of $50 \mathrm{~L} / \mathrm{h}$. The capillary temperature was set at $350^{\circ} \mathrm{C}$. The ESI-MS spectrum recorded in the negative ion mode showed a $[\mathrm{M}-\mathrm{H}]+$ peak at $\mathrm{m} / \mathrm{z} 591$, which was in agreement with the expected molecular weight of $592\left(\mathrm{C}_{28} \mathrm{H}_{32} \mathrm{O}_{14}\right)$ for $2^{\prime \prime}$ $\mathrm{O}$-rhamnosylswertisin. MS/MS analysis showed a loss of 146 mass units (peak at $\mathrm{m} / \mathrm{z} 445$ ), corresponding to the loss of rhamnosyl moiety. Peaks were also observed at $\mathrm{m} / \mathrm{z} 427$ and $\mathrm{m} / \mathrm{z} 324$. It should be pointed out that this is the first report on the MS analysis of this compound.

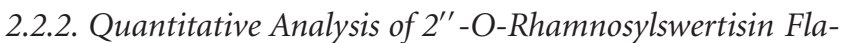
vonoid in Dried Extract. The HPLC system consisted of a Waters 600 pump (Milford, Mass, USA); 2996 PDA detector, automatic 717 plus injector, in line degasser AF, and Millennium Empower software. The injections $(20 \mu \mathrm{L})$ were carried out on a C8 X-Bridge $150 \times 4,6 \mathrm{~mm}$ ( $5 \mathrm{um}$ ) (Waters, Taunton, Mass, USA). The mobile phase consisted of a gradient A (acetonitrile) and B (acidified water $\mathrm{pH} 3.54$ with acetic acid) of $10: 90$ (A : B) (0 min), 25:75 (20 min), and $10: 90$ (30 min), maintaining this composition until $40 \mathrm{~min}$, and a flow rate of $0.5 \mathrm{~mL} \cdot \mathrm{min}^{-1}$. The analysis was monitored at $338 \mathrm{~nm}$ and the column oven fit to $30^{\circ} \mathrm{C}$.

All solvents were HPLC grade (Tedia, Fairfield, Ohio, USA) and were degassed by ultrasonic bath (Unique, Santo Amaro, São Paulo, Brazil). The water was purified using a Milli-Q system (Millipore, Billerica, Mass, USA). All solutions were filtered through $0.45 \mu \mathrm{m}$ membranes (Millipore, Billerica, Mass, USA).

\subsubsection{Pharmacological Studies}

Animals. Female Swiss mice (25-30 g), obtained from the University of Vale do Itajaí (UNIVALI, Itajaí, Brazil), were used throughout this study. Female mice were chosen to investigate mechanical hypernociception based on the literature data, which indicates that females are more susceptible to developing chronic nociception $[14,15]$. The animals were housed under conditions of optimum light, temperature, and humidity ( $12 \mathrm{~h}$ light-dark cycle, $22 \pm 1^{\circ} \mathrm{C}$, 60 to $80 \%$ humidity), with food and water provided ad libitum. All procedures used in the present study followed the "Principles of Laboratory Animal Care" from NIH publication no. 8523 and were approved by the Animal Ethics Committee of UNIVALI (Protocol numbers 416/2008 UNIVALI). The number of animals and the intensity of noxious stimuli 


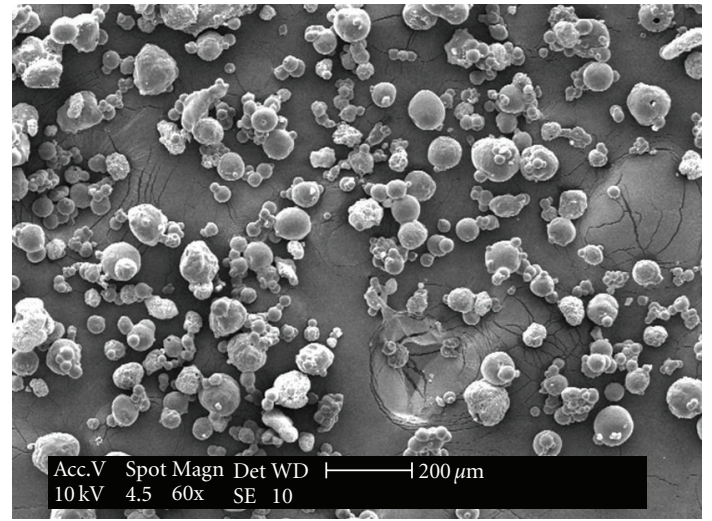

(a)

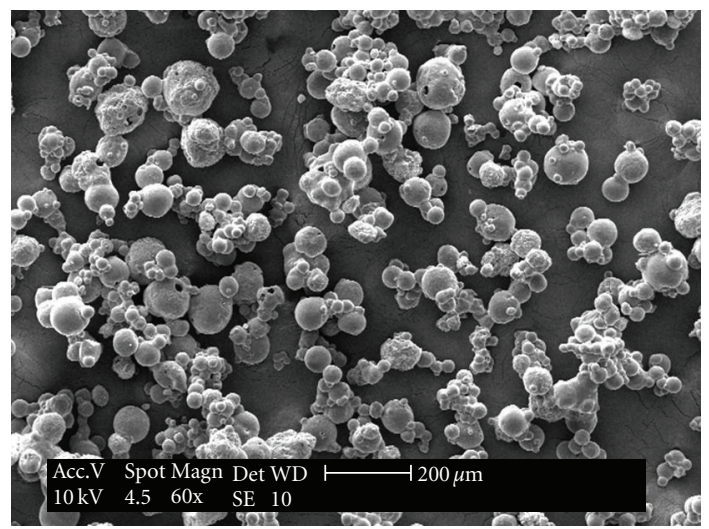

(b)

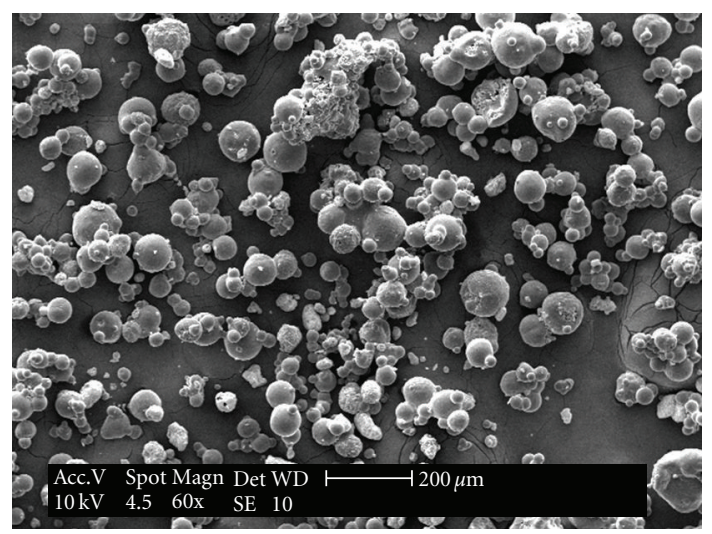

(c)

Figure 3: Scanning electronic microscopy of dried extracts of $A$. moluccana produced in pilot scale. (a) batch 1; (b) batch 2; (c) batch 3.

used were the minimum necessary to demonstrate consistent effects. The number of animals per group was $5-8$.

Carrageenan-Induced Mechanical Hypernociception. To induce inflammatory pain, the mice received an i.d. injection of $50 \mu \mathrm{L}$ of carrageenan $(300 \mu \mathrm{g} / \mathrm{paw})$ under the surface of the right hindpaw [14]. To assess the systemic effect of the drug treatment, the mice received $A$. moluccana SDE (batch
1, 2, or 3; 125-500 mg/kg, p.o.), 2" -O-rhamnosylswertisin (30 mg/kg; $50.6 \mu \mathrm{mol} / \mathrm{kg}$, p.o.), swertisin (30 mg/kg, $67.2 \mu \mathrm{mol} / \mathrm{kg}$, p.o.), indomethacin (0.1-5 mg/kg, p.o.), or vehicle $(10 \mathrm{~mL} / \mathrm{kg}, 0.9 \% \mathrm{NaCl}$ solution $), 1 \mathrm{~h}$ before carrageenan injection. The mechanical hypernociception of all the groups was assessed by means of von Frey filaments (VFH), for up to $48 \mathrm{~h}$ after carrageenan administration, as described below.

CFA-Induced Mechanical Hypernociception. In an attempt to evaluate the preventive effect, the mice were pretreated orally with $A$. moluccana SDE (batch $1 ; 125-500 \mathrm{mg} / \mathrm{kg}$ ), $2^{\prime \prime}$-O-rhamnosylswertisin (10 mg/kg; $16.86 \mu \mathrm{mol} / \mathrm{kg}$, p.o. $)$, indomethacin $(10 \mathrm{mg} / \mathrm{kg}$, p.o.), or vehicle $(10 \mathrm{~mL} / \mathrm{kg}, 0.9 \%$ $\mathrm{NaCl}$ solution). $1 \mathrm{~h}$ afterwards, they received an i.d. injection of complete Freund's adjuvant (CFA) $(1 \mathrm{mg} / \mathrm{mL}$ heatkilled and dried Mycobacterium tuberculosis; each $\mathrm{mL}$ of vehicle contained $0.85 \mathrm{~mL}$ paraffin oil plus $0.15 \mathrm{~mL}$ mannide monooleate; $20 \mu \mathrm{L} /$ paw) in the right hindpaw [16]. Mechanical hypernociception was evaluated for up to $48 \mathrm{~h}$ after CFA injection.

Mechanical Hypernociception Induced by $P G E_{2}$. To evaluate the mechanical hypernociception, mice were treated with A. moluccana SDE (batch $1 ; 125-250 \mathrm{mg} / \mathrm{kg}$, i.p.), $2^{\prime \prime}$-O-rhamnosylswertisin ( $10 \mathrm{mg} / \mathrm{kg} ; 16.86 \mu \mathrm{mol} / \mathrm{kg}$, p.o. $)$, morphine $(5 \mathrm{mg} / \mathrm{kg}, \mathrm{s.c})$, or vehicle $(10 \mathrm{~mL} / \mathrm{kg}, 0.9 \% \mathrm{NaCl}$ solution), $30 \mathrm{~min}$ before the i.d. injection of prostaglandin $\mathrm{E}_{2}$ $\left(\mathrm{PGE}_{2}\right)(0.1 \mathrm{nmol} / \mathrm{paw})$ [16]. The mechanical hypernociception was measured with VFH, as described below, at different time points after the i.d. injection of $\mathrm{PGE}_{2}$.

Von Frey Hair-Induced Hindpaw Withdrawal Response. To evaluate mechanical hypernociception, the mice were individually placed in clear Plexiglas boxes $(9 \times 7 \times 11 \mathrm{~cm})$ on elevated wire mesh platforms, to allow access to the ventral surface of the right hindpaw. The withdrawal response frequency was measured following 10 applications (duration of $1 \mathrm{~s}$ each) of von Frey hairs (VFH, Stoelting, Chicago, Il, USA). The stimuli were delivered from below to the plantar surface of the right hindpaw. The animals were acclimatized for $30 \mathrm{~min}$ before behavioural testing, and mechanical hypernociception was evaluated at several time points. A VFH of $0.6 \mathrm{~g}$ produces a mean withdrawal frequency of about $15 \%$, which is considered to be an adequate value for the measurement of mechanical hypernociception [14, 17]. Therefore, $0.6 \mathrm{~g}$ VFH was used throughout this study. To determine the basal mechanical thresholds, all the groups were evaluated before the test.

Drugs and Reagents. The following drugs and reagents were used: CFA (Sigma Chemical Company, St. Louis, Mo USA); carrageenan, $\mathrm{PGE}_{2}$ (Fluka Riedel-de Haën, Seelze, Germany); indomethacin (DEG Importação de Produtos Químicos Ltda). All the other reagents and solvents used were of analytical grade. 
Statistical Analysis. The results are presented as the mean \pm S.E.M. of 5 to 7 animals, except for the $\mathrm{ID}_{50}$ values (i.e., the dose of A. moluccana DE that reduced the hypernociceptive responses by $50 \%$ relative to the control values), which are presented as means accompanied by their respective $95 \%$ confidence limits. The $\mathrm{ID}_{50}$ values and the percentages of inhibition were based on AUC (area under curve), calculated using the entire time course of each experiment and reported as mean \pm S.E.M. of inhibitions obtained for each individual experiment. Statistical comparison of the data was performed by two-way analysis of variance (ANOVA), followed by Bonferroni's post hoc test and by one-way ANOVA and Dunnett's post hoc test. $P$-values lower than $0.05(P<0.05$ or less $)$ were considered significant.

\section{Results}

3.1. Isolation, Identification, and Purity Determination of Flavonoids. The phytochemical procedures conducted with the crude methanol extract obtained from A. moluccana leaves using silica gel CC and flash chromatography led to the isolation and identification of two main flavone Cglycosides, swertisin (1) and 2"-O-rhamnosylswertisin (2) (Figure 1). Although the spectral data has been previously published [13], this is the first report on the MS analysis of this compound.

Purity analysis was performed by means of HPLC, and at $338 \mathrm{~nm}, 2^{\prime \prime}-O$-rhamnosylswertisin was identified with a $24.5 \mathrm{~min}$ retention time and swertisin with a $25.5 \mathrm{~min}$ retention time Figure 2(a). After integration of all the peaks at $338 \mathrm{~nm}$, a purity $>95 \%$ of flavonoids was calculated, Figure 2(a).

3.2. Preparation of Standardized Dried Extract. The A. moluccana dried extract batches obtained in pilot scale by spray drier showed similar physical and chemical characteristics, Table 1. The dried extracts are characterized as fine and hygroscopic powder, spherical particles with a smooth surface, greenish brown in color, with approximately 3\% moisture (Figure 3). The 2"-O-rhamnosylswertisin content of the extracts was similar, and the physical and chemical results were in agreement with the data obtained in previous studies to optimize the extraction process and biological activity in vivo.

The chromatographic profile of dried extract by HPLC showed the presence of various flavonoid compounds including $2^{\prime \prime}$-O-rhamnosylswertisin (the major component, peak 8) and swertisin (peak 9), Figure 2(a).

3.3. Pharmacological Studies. Figures 4(a) and 4(b) demonstrate that i.d. injection of carrageenan $(300 \mu \mathrm{g} / \mathrm{paw})$ significantly reduced the mechanical sensitivity threshold $(P<$ $0.05)$, when compared to the response rate of the control group with animals injected with saline solution and basal thresholds. The oral treatment with A. moluccana $(500 \mathrm{mg} / \mathrm{kg})$ was able to reduce the mechanical hypernociception induced by i.d. injection of carrageenan, with inhibition of $36 \pm 4 \%$ and $\mathrm{ID}_{50} \%$ of $443(400-490) \mathrm{mg} / \mathrm{kg}$. Indomethacin, a non steroidal antiinflammatory drug used as a positive control, was also capable of inhibiting the mechanical sensitization induced by carrageenan, with inhibition of $38 \pm 5 \%$.

Significant results were obtained with animals injected with CFA, where A. moluccana SDE (batch $1 ; 500 \mathrm{mg} / \mathrm{kg}$, p.o.) reduced the hypernociceptive threshold for up to $6 \mathrm{~h}$ after CFA paw injection, with inhibition of $48 \pm 4 \%$ at a dose of $500 \mathrm{mg} / \mathrm{kg}$, see Figures 4(c) and 4(d). The nonsteroid antiinflammatory drug indomethacin $(10 \mathrm{mg} / \mathrm{kg}$, p.o. $)$, dosed orally, did not interfere with the hypernociceptive threshold induced by CFA in mice.

As illustrated in Figures 4(e) and 4(f), i.d. injection of $\mathrm{PGE}_{2}(0.1 \mathrm{nmol} / \mathrm{paw})$ into the mouse hindpaw produced prominent mechanical hypernociceptive effects lasting for up to $24 \mathrm{~h}$, as indicated by a marked increase in baseline values in response to $0.6 \mathrm{~g}$ VFH stimulation. A. moluccana DE (batch 1; 125 to $500 \mathrm{mg} / \mathrm{kg}$, p.o., $1 \mathrm{~h}$ ) proved to be effective in significantly preventing $\mathrm{PGE}_{2}$-induced mechanical hypernociception up to $1 \mathrm{~h}$ after the irritant agent injection, Figures $4(\mathrm{e})$ and $4(\mathrm{f})$. The percentages of reduction were $26 \pm 10 \%$ and $33 \pm 3 \%$, for 250 and $500 \mathrm{mg} / \mathrm{kg}$, respectively. Morphine $(5 \mathrm{mg} / \mathrm{kg}$, s.c.), the drug used as positive control, reduced the hypernociceptive response induced by $\mathrm{PGE}_{2}$, with inhibition of $48 \pm 6 \%$, Figure 4 (f).

The antinociceptive effect of the isolated markers, swertisin and $2^{\prime \prime}$-O-rhamnosylswertisin $(30 \mathrm{mg} / \mathrm{kg}$, p.o., $1 \mathrm{~h}$ before), was also investigated in the carrageenan-induced mechanical hypernociception model in mice. Figures 5(a) and 5(b) demonstrate that both swertisin and 2"-Orhamnosylswertisin were effective in inhibiting the hypernociceptive response, when compared with the control group, with inhibitions of $70 \pm 2 \%$ and $50 \pm 5 \%$, respectively. Furthermore, 2" -O-rhamnosylswertisin was capable of significantly inhibiting the mechanical sensitization induced by $\mathrm{CFA}$ or $\mathrm{PGE}_{2}$, with inhibitions of $25 \pm 3 \%$ and $94 \pm 6 \%$, respectively, see Figures 5(c) and 5(d). 2"$O$-rhamnosylswertisin accounts for $3 \%$ of the dried extract obtained from A. moluccana, as evidenced by HPLC, see Figure 2.

Finally, when the dried extract produced in the scaleup was tested, all three batches had the same effect when compared with the previous studies, Figures 6(a) and 6(b). It is important to mention that the results obtained with the dose of $250 \mathrm{mg} / \mathrm{kg}$ presented in Figure 4(a) are significantly different from the control group, although the AUC representation did not demonstrate the same.

\section{Discussion}

This paper describes the isolation, purification, characterization, and pharmacological effects of the chemical marker $2^{\prime \prime}$ $O$-rhamnosylswertisin and swertisin from leaves of A. moluccana. Although these flavonoids have been found in other plants, they are considered rare in higher plants and have not been described for plants belonging to the Euphorbiaceae family. These markers are important for the quality assurance 


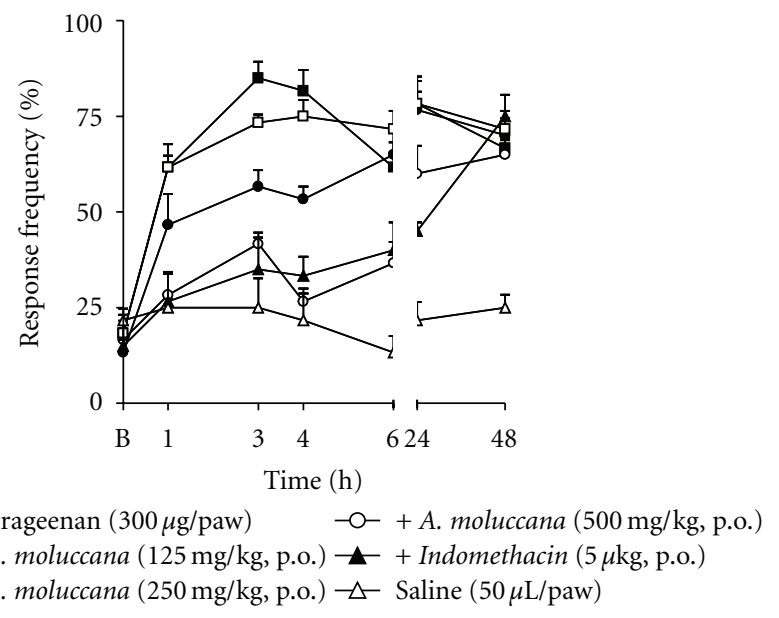

(a)
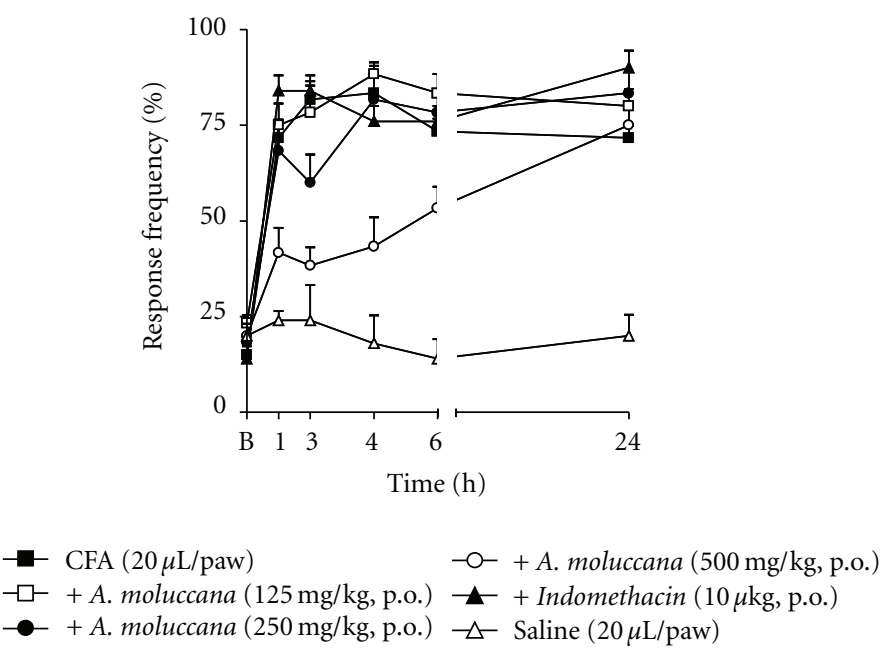

(c)

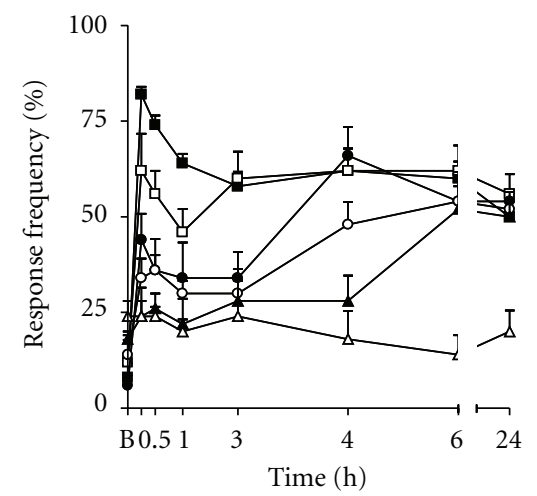

\footnotetext{
$\rightarrow \mathrm{PGE}_{2}(0.1 \mathrm{nmol} / \mathrm{paw})$

+ A. moluccana $(125 \mathrm{mg} / \mathrm{kg}$, p.o.)

+ A. moluccana $(250 \mathrm{mg} / \mathrm{kg}$, p.o.)

$-\mathrm{O} \quad+$ A. moluccana $(500 \mathrm{mg} / \mathrm{kg}$, p.o. $)$

$\leftarrow+$ morphine $(5 \mathrm{mg} / \mathrm{kg}$, s.c. $)$
}

(e)

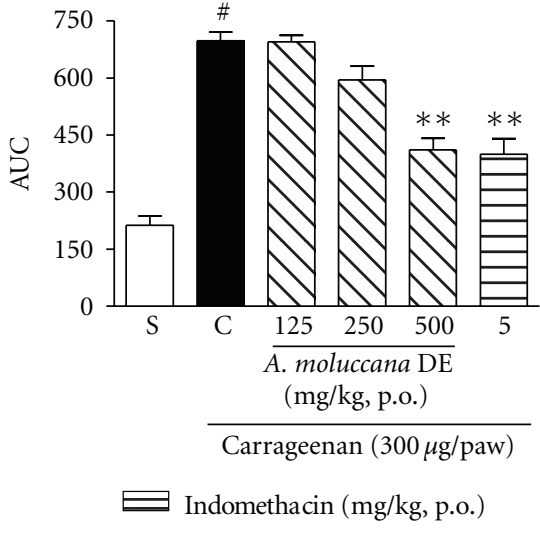

(b)

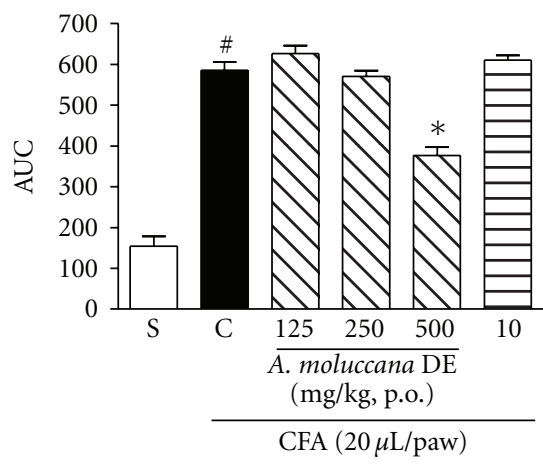

E Indomethacin (mg/kg, p.o.)

(d)

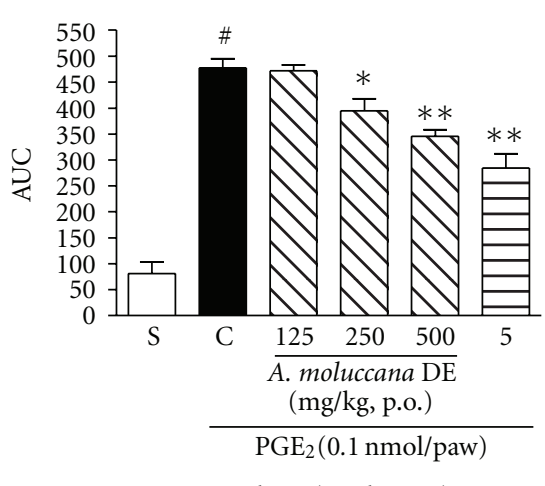

(f)

Figure 4: Effects of A. moluccana DE (batch 1; 125-500 mg/kg, p.o.) in mechanical hypernociception induced by i.d. injection of ((a) and (b)) carrageenan $(300 \mu \mathrm{g} / \mathrm{paw}),\left((\mathrm{c})\right.$ and (d) $\mathrm{CFA}(20 \mu \mathrm{L} / \mathrm{paw})$, or ((e) and (f)) $\mathrm{PGE}_{2}(0.1 \mathrm{nmol} / \mathrm{paw})$ in mice. Each group represents the mean of 5 to 8 animals, and the vertical lines indicate the SEM. Significantly different from the control values $* P<0.05$ and significantly different from saline group ${ }^{\#} P<0.001$ (two-way ANOVA followed by Bonfferroni's post hoc test and one-way ANOVA followed by Dunnett's post hoc test). 


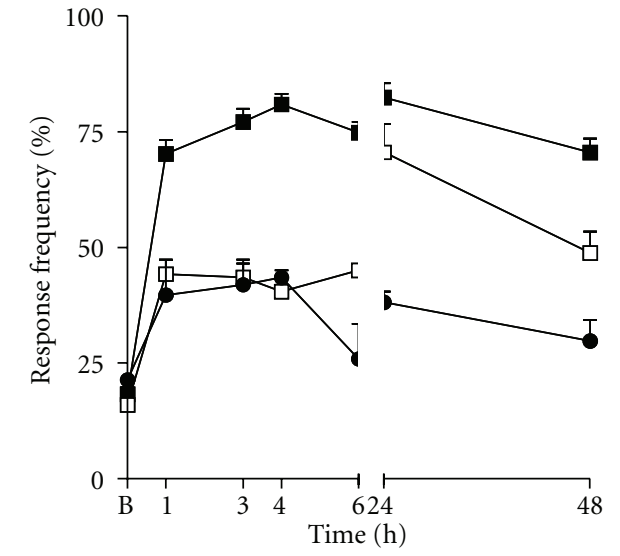

- Carrageenan $(300 \mu \mathrm{g} / \mathrm{paw})$

$-\square-2^{\prime \prime}-O$-rhamnosylswertisin (30 mg/kg, p.o.)

(a)

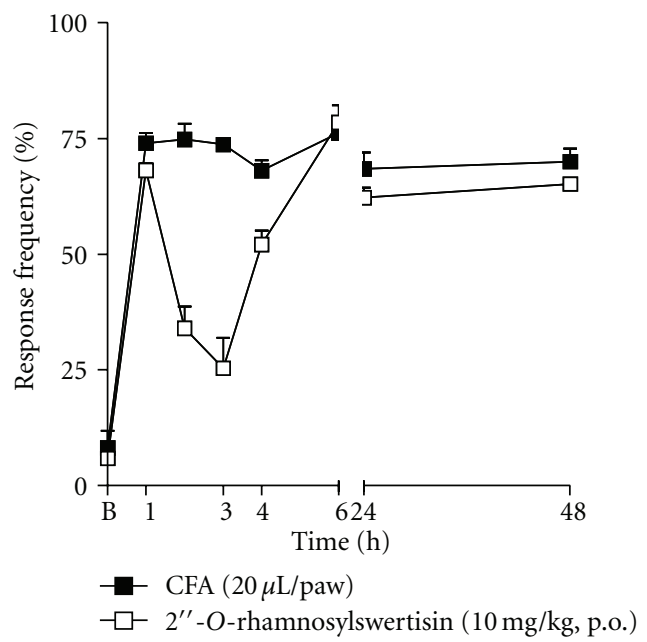

(c)

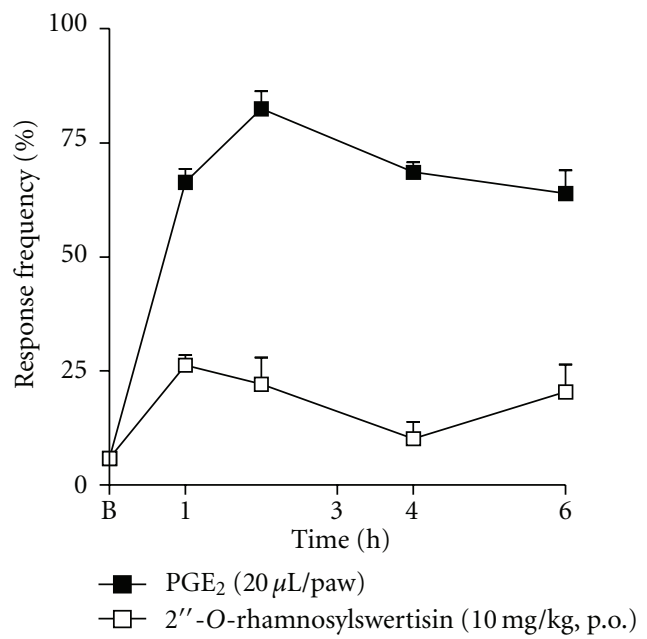

(e)

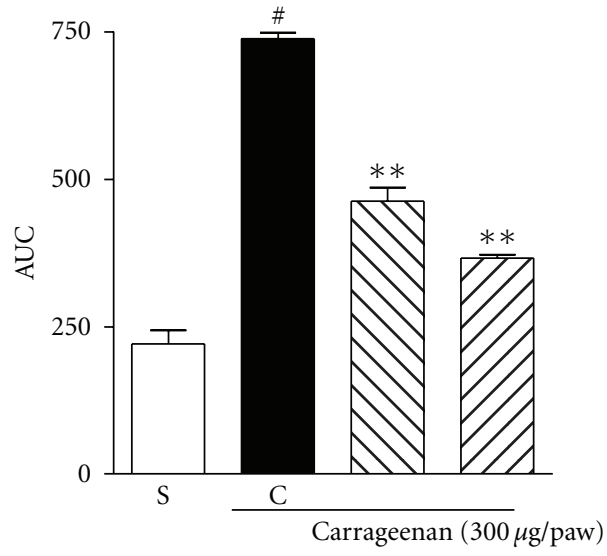

$\Delta \nabla 2$ 2" -O-rhamnosylswertisin (10 mg/kg, p.o.) $\square$ Swertisin (30 mg/kg, p.o.)

(b)

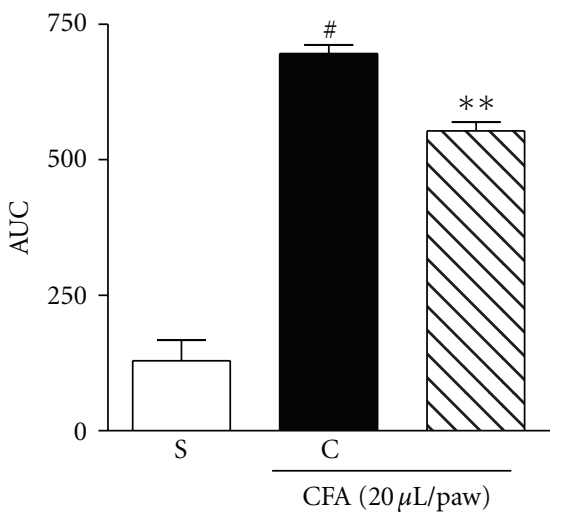

$\square \quad 2^{\prime \prime}-O$-rhamnosylswertisin (10 mg/kg, p.o.)

(d)

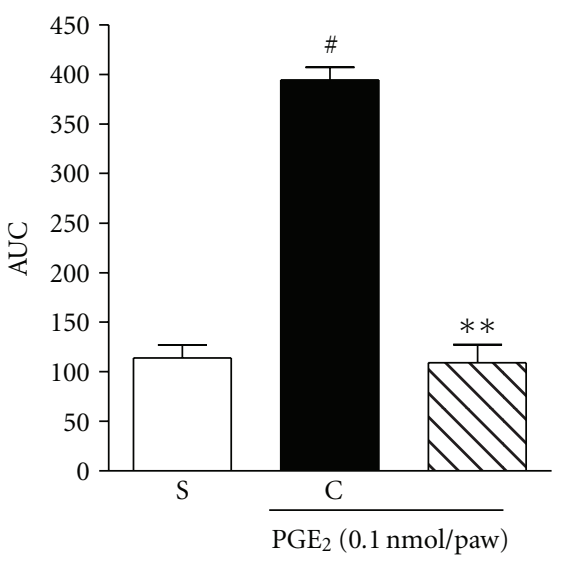

$\triangle 2^{\prime \prime}-O$-rhamnosylswertisin $(10 \mathrm{mg} / \mathrm{kg}$, p.o.)

(f)

Figure 5: ((a) and (b)) Effects of the isolated compounds $2^{\prime \prime}$-O-rhamnosylswertisin and swertisin, administered orally (30 or $10 \mathrm{mg} / \mathrm{kg}, 1 \mathrm{~h}$ before) in mechanical hypernociception induced by i.d. injection of ((a) and (b)) carrageenan $(300 \mu \mathrm{g} / \mathrm{paw}),((\mathrm{c})$ and (d)) CFA (20 $\mu \mathrm{L} /$ paw) or ((e) and (f)) $\mathrm{PGE}_{2}(0.1 \mathrm{nmol} / \mathrm{paw})$ in mice. Each group represents the mean of 5 to 8 animals, and the vertical lines indicate the SEM. Significantly different from the control values ${ }^{*} P<0.05$ and ${ }^{* *} P<0.01$ and significantly different from the saline group ${ }^{\#} P<0.001$ (two-way ANOVA followed by Bonfferroni's post hoc test and one-way ANOVA followed by Dunnett's post hoc test). 
TABle 1: Physical and chemical characteristics of dried extracts of Aleurites moluccana produced in pilot scale.

\begin{tabular}{|c|c|c|c|}
\hline \multirow{2}{*}{ Parameters } & \multicolumn{3}{|c|}{ Dried extract batch } \\
\hline & 1 & 2 & 3 \\
\hline Aspect & Fine, hygroscopic powder & Fine, hygroscopic powder & Fine, hygroscopic powder \\
\hline Color & greenish brown & greenish brown & greenish brown \\
\hline Taste/odor & characteristic & characteristic & characteristic \\
\hline Moisture (\%) & 2.6 & 3.0 & 3.4 \\
\hline Average size $(\mu \mathrm{m})$ & 120.54 & 151.12 & 112.69 \\
\hline $\mathrm{pH}$ & 4.95 & 4.76 & 4.77 \\
\hline Bulk density $(\mathrm{g} / \mathrm{mL})$ & 0.6386 & 0.5757 & 0.6152 \\
\hline $2^{\prime \prime}$-O-rhamnosylswertisin content $(\% \mathrm{w} / \mathrm{w})$ & 3.01 & 2.76 & 2.91 \\
\hline
\end{tabular}

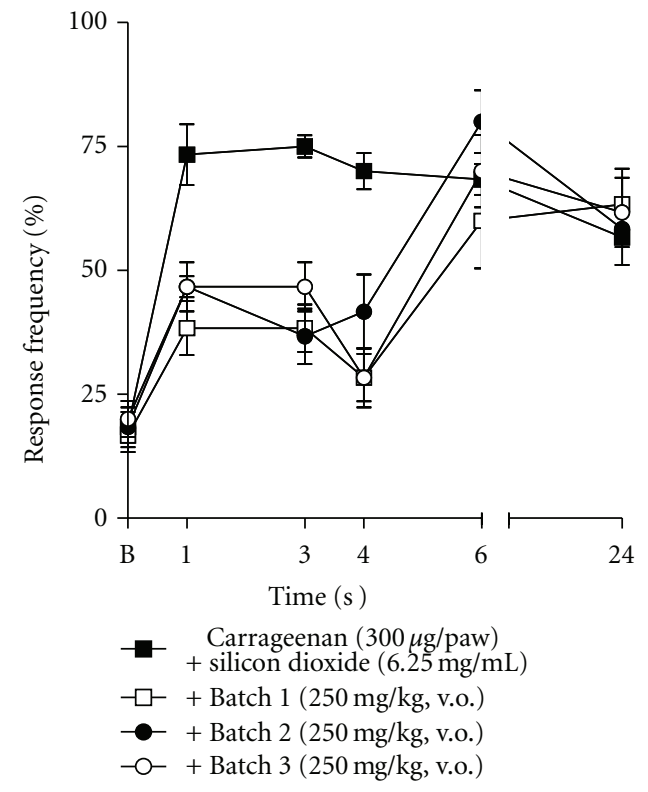

(a)

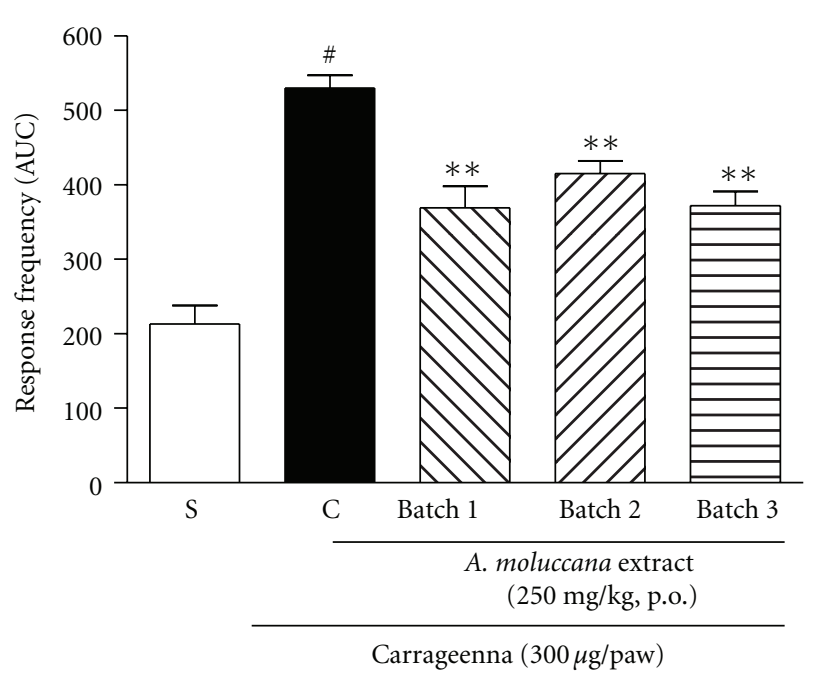

(b)

Figure 6: ((a) and (b)) Effects of the A. moluccana extract batch 1, 2, or 3, administered orally ( $250 \mathrm{mg} / \mathrm{kg}, 1 \mathrm{~h} \mathrm{before),} \mathrm{in} \mathrm{the} \mathrm{mechanical}$ hypernociception induced by i.d. injection of carrageenan $(300 \mu \mathrm{g} / \mathrm{paw})$ in mice. Each group represents the mean of 5 to 8 animals, and the vertical lines indicate the SEM. Significantly different from the control values ${ }^{* *} P<0.01$ and significantly different from the saline group ${ }^{\#} P<0.001$ (two-way ANOVA followed by Bonfferroni's post-hoc test and one-way ANOVA followed by Dunnett's post-hoc test).

of each step in the phytomedicines development and also to elucidate its pharmacological activity.

The methodology of SDE preparation in the pilot scale shows reproducibility and feasibility for use in extract production on an industrial scale. Also, the HPLC-developed method allowed the standardization of the extract for the future development of a phytomedicine.

The drugs used to treat chronic inflammatory conditions are not as effective and display pharmacological effect acting only on the inhibition of production of prostanoids but not interfering with other important elements of the cascade of inflammation. Thus, the pharmacological validation of natural products with established use in folk medicine in these types of conditions is very important. The pharmacologic effect of SDE and the markers was evaluated in a model of mechanical hypernociception induced by important flogistic agents such as carrageenan, $\mathrm{PGE}_{2}$, and CFA. Our study initially demonstrated the effect of SDE in the mechanical hypernociception induced by i.d. injection of carrageenan in mice. Carrageenan is an inflammatory agent that is largely used as pharmacological tool for investigating inflammatory hyperalgesia in rats and mice [18]. When injected intradermally on the plantar surface of animal's hindpaw, it induces an inflammatory process associated with hyperalgesia [19]. Tissue injury originating after the injection of carrageenan involves the release of different chemical mediators such as $\mathrm{PGE}_{2}$ [20], mast cells products histamine and serotonin [21], neuropeptides [22], and cytokines (TNF $\alpha$ and IL-1 $\beta$ ) [23], among others [23]. This effect was similar when compared with animals treated with indomethacin. This result suggests that SDE of A. moluccana may be interfering with different pathways involved in inflammatory pain signaling.

The effect of SDE against inflammatory hypernociception induced by i.d. injection of CFA and $\mathrm{PGE}_{2}$ was also investigated. The CFA model has significant proximity with chronic inflammatory diseases in humans, such as rheumatoid arthritis. The inflammatory response induced by CFA develops rapidly and can persist for several weeks or 
months [14]. The hypernociceptive response is mediated by local sensitization of nociceptors and also involves immune response and changes in the central nervous system [24]. It is now well established that inflammatory hypernociception, such as that induced by $\mathrm{PGE}_{2}$, depends on the activation of signalling pathways, which require neuronal activation of PKA in neurons, downstream of the second messenger cAMP [25]. Moreover, there many studies suggesting that the PKC pathway also participates in nociceptor sensitization, induced by nociceptive mediators, such as adrenaline, endothelins, and bradykinin, as well as by more general inflammation.

These pharmacological data reinforce the fact that part of the antihypernocicepive effect observed with dried extract obtained from A. moluccana is probably due to the action of the isolated compounds $2^{\prime \prime}$-O-rhamnosylswertisin and swertisin. The role of flavonoids in the effects of $A$. moluccana, modulating the nociceptive threshold, can be hypothesized, since it has been extensively reported that this class of compounds is responsible for the antiinflammatory and anti-nociceptive effects of several herbal products, such as rutin, quercetin, and myricitrin, among others in animal models of pain and acute inflammation [26-28]. In addition, several flavonoids, including quercetin and myricitrin are also effective in reducing hypernociception in models of chronic inflammatory pain [29-31].

Previous studies conducted with the flavonoid swertisin revealed its potential as an agent that stimulates insulin secretion presenting antihyperglycemic effect [32], but no analgesic studies with this flavonoid have yet been conducted; except for tge work in [33] done on the flavonoidenriched fraction from Cayaponia tayuya roots which included swertisin.

Recent studies conducted at our laboratories have indicated the absence of toxicological effects of this extract in two different animal species (unpublished results). In addition, no cases of intoxication by this Aleurites species were found in the literature [34].

It is also suggested that dried extract of $A$. moluccana, dosed systemically, may be acting on the peripheral and/or on the central pathways of pain control. The mechanisms through which A. Moluccana, and its marker $2^{\prime \prime}$-O-rhamnosylswertisin, exert their anti-hypernociceptive actions are currently unclear and require further investigation; however, this could well constitute a new and attractive alternative for the management of inflammatory pain in humans using natural product. In view of the need for new safe and effective therapies, and taking into account the adverse effects associated with the drugs currently used, $A$. moluccana represents an important and promising source of herbal medicine for the treatment of pathologies for which no efficacious treatment exists, such as chronic pain.

\section{Conclusion}

The standardized dried extract of A. moluccana with 3\% of the marker $2^{\prime \prime}-O$-rhamnosylswertisin was obtained in a reproducibility scaleup method. Furthermore, the extract showed potential antinociceptive effects in an experimental model of inflammatory mechanical sensitization, using different inductor agent, such as $\lambda$-carrageenan, CFA, or $\mathrm{PGE}_{2}$ in mice. The biological effect of the extract may be attributed, at least in part, to the marker $2^{\prime \prime}$-O-rhamnosylswertisin and to the other flavonoid, swertisin, present in minor amounts. These promising results support further studies aimed at developing a new herbal medicine based on a tree used in traditional folk medicine, contributing to the treatment of painful processes.

\section{Acknowledgments}

The authors wish to thank the Laboratório Farmacêutico Eurofarma (São Paulo, Brazil), FINEP/MCT (Financiadora de Estudos e Projetos/Ministério da Ciência e Tecnologia) (no. 01.05.0812.00), CNPq (Conselho Nacional de Ciência e Tecnologia), MS/DECIT (Ministério da Saúde/Departamento de Ciência e Tecnologia da Secretaria de Ciência, Tecnologia e Insumos Estratégicos), CT-BIOTEC (Fundos Setoriais de Biotecnologia), and CT-Saúde (Fundos Setoriais de Saúde (Edital Bioinova no. 551023/2007-4) for their financial support during this study. C. S. Antonialli and G. F. Silva are M.S. students in pharmaceutical Science supported by grants from the CNPq.

\section{References}

[1] P. M. Corrêa, Dicionário das plantas úteis do Brasil e das exóticas cultivadas, Imprensa Nacional Rio de Janeiro, Rio de Janeiro, Brazil, 1984.

[2] J. A. Duke, Handbook of Medicinal Herbs, CRC Press, Boca Raton, Fla, USA, 1990.

[3] C. P. Locher, M. Witvrouw, M. P. De Bethune et al., "Antiviral activity of Hawaiian medicinal plants against human immunodeficiency virus type-1 (HIV-1)," Phytomedicine, vol. 2, no. 3, pp. 259-264, 1996.

[4] C. P. Locher, M. T. Burch, H. F. Mower et al., "Antimicrobial activity and anti-complement activity of extracts obtained from selected Hawaiian medicinal plants," Journal of Ethnopharmacology, vol. 49, no. 1, pp. 23-32, 1995.

[5] R. C. Pedrosa, C. Meyre-Silva, V. Cechinel-Filho et al., "Hypolipidaemic activity of methanol extract of Aleurites moluccana," Phytotherapy Research, vol. 16, no. 8, pp. 765-768, 2002.

[6] J. A. Duke, "The quest for tolerant germplasm," in Crop Tolerance to Suboptimal Land Conditions, ASA Special Symposium 32, pp. 1-61, American Society of Agronomy, Madison, WI, USA, 1978.

[7] V. Cechinel Filho, T. M. B. Bresolin, C. M. S. Bittencourt et al., "Pedreira M The process of obtaining an extract, obtained extract, pharmaceutical composition, method of treatment and use of this extract," Patente PI 0804525-9 A2 (22), 2008.

[8] C. Meyre-Silva, T. C. Mora, M. W. Biavatti et al., "Preliminary phytochemical and pharmacological studies of Aleurites moluccana leaves [L.] Willd," Phytomedicine, vol. 5, no. 2, pp. 109-113, 1998.

[9] C. Meyre-Silva, R. A. Yunes, A. R. S. Santos, J. Dal Magro, F. Delle-Monache, and V. Cechinel-Filho, "Isolation of a Cglycoside flavonoid with antinociceptive action from Aleurites 
moluccana leaves," Planta Medica, vol. 65, no. 3, pp. 293-294, 1999.

[10] United States Pharmacopeia 32th edn, NF 27, United States Pharmacopeial Convention, Rockville, Md, USA, 2009.

[11] S. Shirane, S. Ohya, T. Matsuo et al., "C-glycosyl compounds in the leaves of Gemmingia chinensis O. Kuntze," Agricultural and Biological Chemistry, vol. 46, no. 10, pp. 2595-2597, 1982.

[12] M. Komatsu, T. Tomimori, and M. Ito, "Studies on the constituents of Swertia japonica. I. On the structures of swertisin and isoswertisin," Chemical and Pharmaceutical Bulletin, vol. 15, no. 3, pp. 263-269, 1967.

[13] R. A. Hilsenbeck and T. J. Mabry, "Flavonoid chemistry of Siphonoglossa," Phytochemistry, vol. 29, no. 7, pp. 2181-2185, 1990.

[14] N. L. M. Quintão, R. Medeiros, A. R. S. Santos, M. M. Campos, and J. B. Calixto, "The effects of diacerhein on mechanical allodynia in inflammatory and neuropathic models of nociception in mice," Anesthesia and Analgesia, vol. 101, no. 6, pp. 1763-1769, 2005.

[15] J. S. Mogil, J. Ritchie, S. G. Sotocinal et al., "Screening for pain phenotypes: analysis of three congenic mouse strains on a battery of nine nociceptive assays," Pain, vol. 126, no. 1-3, pp. 24-34, 2006.

[16] C. A. L. Kassuya, J. Ferreira, R. F. Claudino, and J. B. Calixto, "Intraplantar PGE causes nociceptive behaviour and mechanical allodynia: the role of prostanoid e receptors and protein kinases," British Journal of Pharmacology, vol. 150, no. 6, pp. 727-737, 2007.

[17] L. B. Bortalanza, J. Ferreira, S. C. Hess, F. Delle Monache, R. A. Yunes, and J. B. Calixto, "Anti-allodynic action of the tormentic acid, a triterpene isolated from plant, against neuropathic and inflammatory persistent pain in mice," European Journal of Pharmacology, vol. 453, no. 2-3, pp. 203-208, 2002.

[18] M. L. Vale, V. M. Benevides, D. Sachs et al., "Antihyperalgesic effect of pentoxifylline on experimental inflammatory pain," British Journal of Pharmacology, vol. 143, no. 7, pp. 833-844, 2004.

[19] D. Salvemini, Z. Q. Wang, D. M. Bourdon, M. K. Stern, M. G. Currie, and P. T. Manning, "Evidence of peroxynitrite involvement in the carrageenan-induced rat paw edema," European Journal of Pharmacology, vol. 303, no. 3, pp. 217220, 1996.

[20] S. Oh-Ishi, "Regulation of biological functions by the kallikrein-kinin system," Yakugaku Zasshi, vol. 117, no. 10-11, pp. 739-748, 1997.

[21] L. Kocher, F. Anton, and P. W. Reeh, "The effect of carrageenan-induced inflammation on the sensitivity of unmyelinated skin nociceptors in the rat," Pain, vol. 29, no. 3, pp. 363-373, 1987.

[22] T. J. Coderre and R. Melzack, "Central neural mediators of secondary hyperalgesia following heat injury in rats: neuropeptides and excitatory amino acids," Neuroscience Letters, vol. 131, no. 1, pp. 71-74, 1991.

[23] T. M. Cunha, W. A. Verri, J. S. Silva, S. Poole, F. Q. Cunha, and S. H. Ferreira, "A cascade of cytokines mediates mechanical inflammatory hypernociception in mice," Proceedings of the National Academy of Sciences of the United States of America, vol. 102, no. 5, pp. 1755-1760, 2005.

[24] T. A. Samad, K. A. Moore, A. Sapirstein et al., "Interleukin$1 \beta$-mediated induction of Cox-2 in the CNS contributes to inflammatory pain hypersensitivity," Nature, vol. 410, no. 6827, pp. 471-475, 2001.

[25] C. A. L. Kassuya, J. Ferreira, R. F. Claudino, and J. B. Calixto, "Intraplantar PGE causes nociceptive behaviour and mechanical allodynia: the role of prostanoid e receptors and protein kinases," British Journal of Pharmacology, vol. 150, no. 6, pp. 727-737, 2007.

[26] J. M. Tall and S. N. Raja, "Dietary Constituents as Novel Therapies for Pain," Clinical Journal of Pain, vol. 20, no. 1, pp. 19-26, 2004.

[27] A. W. Filho, V. C. Filho, L. Olinger, and M. M. de Souza, "Quercetin: further investigation of its antinociceptive properties and mechanisms of action," Archives of Pharmacal Research, vol. 31, no. 6, pp. 713-721, 2008.

[28] F. D. R. Lapa, V. M. Gadotti, F. C. Missau et al., "Antinociceptive properties of the hydroalcoholic extract and the flavonoid rutin obtained from Polygala paniculata L. in Mice," Basic and Clinical Pharmacology and Toxicology, vol. 104, no. 4, pp. 306315, 2009.

[29] F. C. Meotti, F. C. Missau, J. Ferreira et al., "Anti-allodynic property of flavonoid myricitrin in models of persistent inflammatory and neuropathic pain in mice," Biochemical Pharmacology, vol. 72, no. 12, pp. 1707-1713, 2006.

[30] F. C. Meotti, A. P. Luiz, M. G. Pizzolatti, C. A. L. Kassuya, J. B. Calixto, and A. R. S. Santos, "Analysis of the antinociceptive effect of the flavonoid myricitrin: evidence for a role of the Larginine-nitric oxide and protein kinase C pathways," Journal of Pharmacology and Experimental Therapeutics, vol. 316, no. 2, pp. 789-796, 2006.

[31] D. A. Valério, S. R. Georgetti, D. A. Magro et al., "Quercetin reduces inflammatory pain: inhibition of oxidative stress and cytokine production," Journal of Natural Products, vol. 72, no. 11, pp. 1975-1979, 2009.

[32] P. Folador, L. H. Cazarolli, A. C. Gazola, F. H. Reginatto, E. P. Schenkel, and F. R. M. B. Silva, "Potential insulin secretagogue effects of isovitexin and swertisin isolated from Wilbrandia ebracteata roots in non-diabetic rats," Fitoterapia, vol. 81, no. 8, pp. 1180-1187, 2010.

[33] S. Aquila, R. M. Giner, M. C. Recio, E. D. Spegazzini, and J. L. Ríos, "Anti-inflammatory activity of flavonoids from Cayaponia tayuya roots," Journal of Ethnopharmacology, vol. 121, no. 2, pp. 333-337, 2009.

[34] M. A. Pinillos, C. Beamount, C. Jean Louis, C. Rubio, J. J. Martinez, and N. Velilla, "Intoxicación por "Nuez de la India" (Alleurites moluccana)," Critical Reviews in Toxicology, vol. 24, p. 83, 2007. 


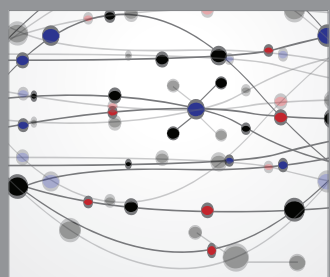

The Scientific World Journal
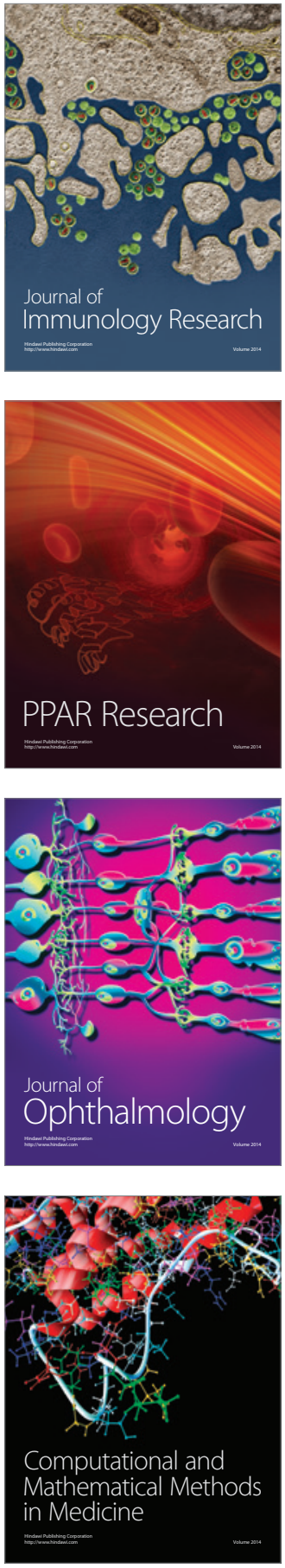

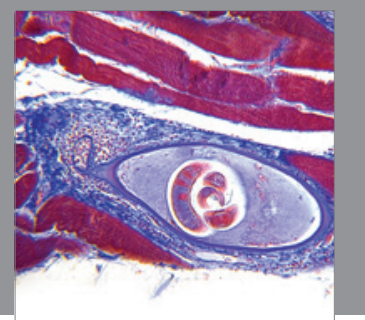

Gastroenterology

Research and Practice
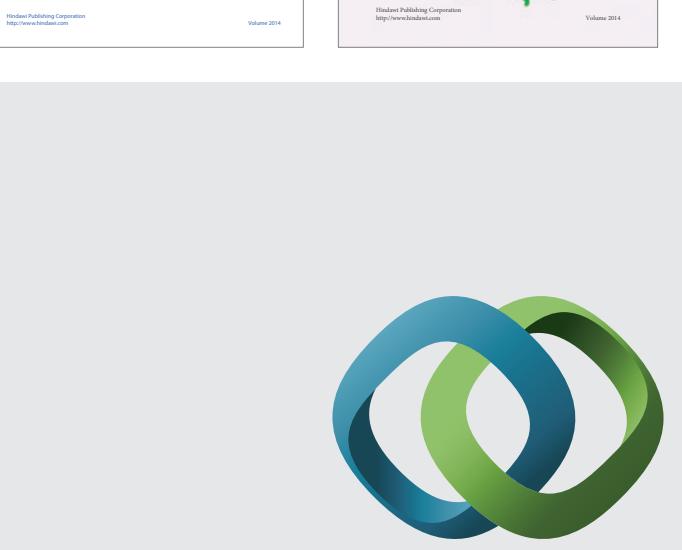

\section{Hindawi}

Submit your manuscripts at

http://www.hindawi.com
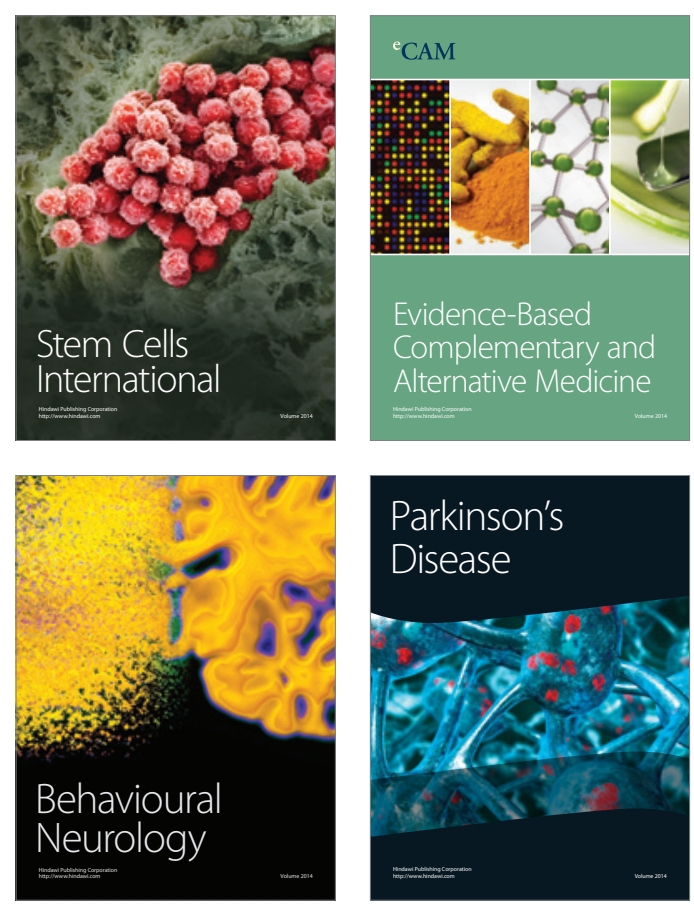

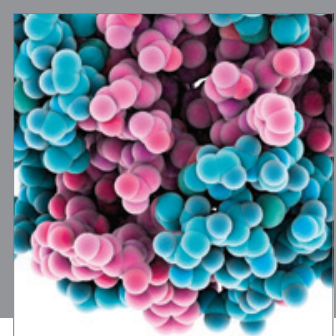

Journal of
Diabetes Research

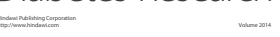

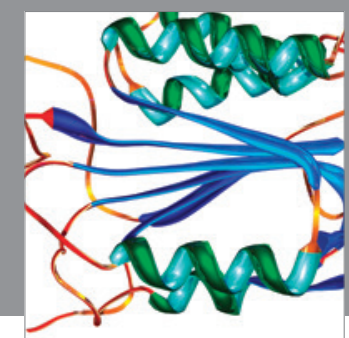

Disease Markers
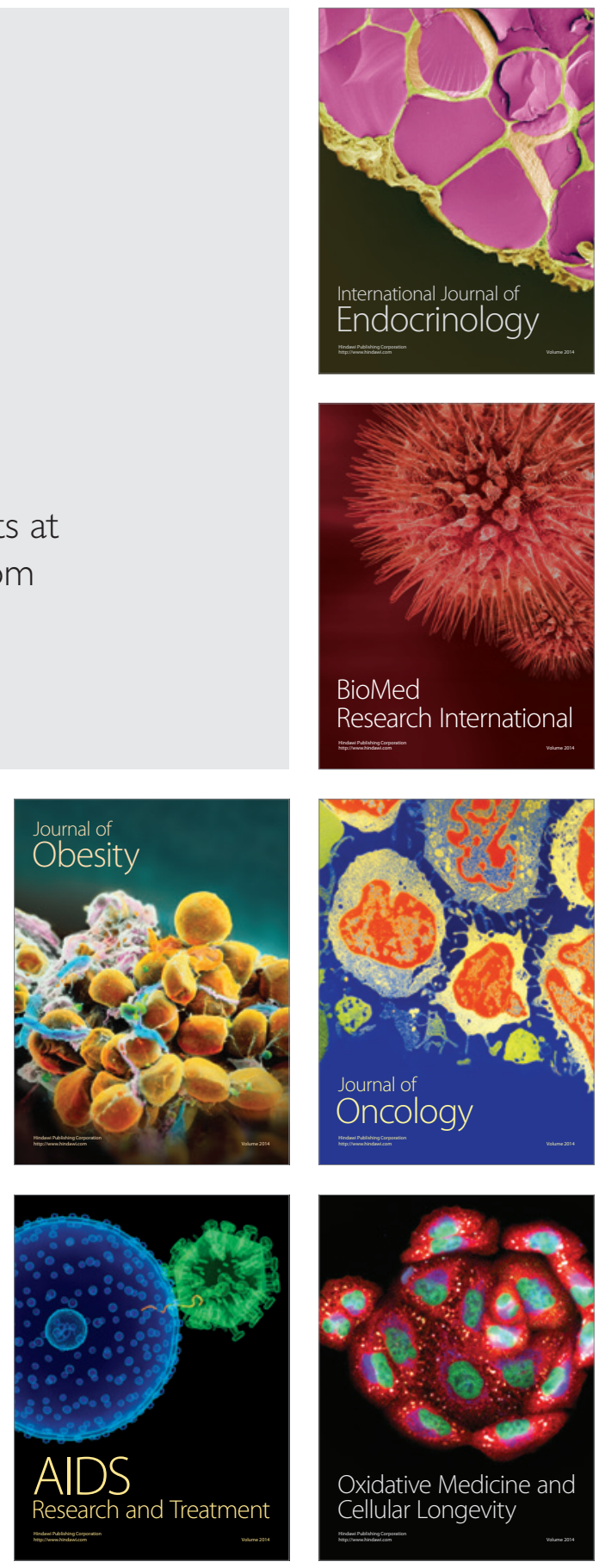